\title{
Application of Proper Nouns as Terms of Address in Russian Compared to their Persian Equivalents
}

\author{
Hasanzadeh Rezvan ${ }^{1}$ \\ Assistant Professor at the Department of Russian and Slavic Languages and \\ Literatures, Faculty of Literature and Humanities, Shahid Beheshti University \\ Tehran, Iran.
}

(date of receiving: November, 2017; date of acceptance: February, 2018)

\begin{abstract}
This study delved into the application of proper nouns as terms of address in Russian and Persian. In other words, it examined the rules governing the application of terms of address expressed as the names of individuals in different speech situations in both languages. The comparative study of the cultural features of languages spoken by Russians and Iranians called for the investigation of this subject. This is the first study to examine the application of proper nouns as terms of address in Russian and Persian focusing on their cultural-linguistic features. The findings suggest that the choice of terms of address depends on factors such as the degree of familiarity with the person being addressed, formality and informality of the speech situation, age, social status, gender, and even cultural, personality, and religious characteristics of those involved in the speech communication. The results of this study can benefit not only Iranian students who learn Russian, but also Russian speakers who learn Persian as a foreign language. This study employed descriptive and comparative linguistics research methods.
\end{abstract}

Keywords: Russian as a Foreign Language, Terms of Address, Speech and Speech Culture, Manners of Speech, Proper Nouns, Persian.

1. E-mail: re_hassanzadeh@sbu.ac.ir 


\title{
Анализ функционирования собственных имен в качестве слов- обращений в русском языке в сопоставлении с их эквивалентами в персидском языке
}

\author{
Хасан-заде Резван ${ }^{1}$ \\ Преподаватель кафедры русского языка и литературы и славянских языков, \\ Университет им. Шахида Бехешти, \\ Тегеран, Иран.
}

(дата получения: ноябрь 2017 г.; дата принятия: февраль 2018 г.)

\begin{abstract}
Аннотация
Тема данной статьи посвящена изучению функционирования собственных имен в виде обращений в русском и персидском языках. В ней изучены правила употребления собственно-именных обращений (личные имена), распространенных в обоих языках в различных коммуникативных сферах общения. Выбор темы вызван, прежде всего, актуальностью изучения особенностей речевых культур и традиций народов Ирана и России. Новизна исследования заключается в том, что впервые сопоставляются собственно-именные слова-обращения в русском и персидском языках сквозь призму лингвокультурологических особенностей этих двух языков. Объектом исследования данной статьи послужили русские и персидские формы обращений, выраженных собственными именами, в различных коммуникативных сферах изучаемых языков. Результаты исследования показывают, что выбор обращений зависит от коммуникативной ситуации: это степень знакомства с адресатом, официальность или неофициальность речевой ситуации, возраст и социальный фактор адресата, и его половая принадлежность, здесь также учитываются лингвокультурологические, мировоззренческие особенности, как адресатов, так и адресантов общения, и даже их личностные черты характера и манеры их поведения. Результаты данного исследования могут быть полезными не только студентам, изучающим РКИ в иранской аудитории, но и русскоговорящим учащимся персидскому языку как иностранному. В ходе выполнения работы используются описательный и сравнительно-сопоставительный метод.
\end{abstract}

Ключевые слова: Русский Язык Как Иностранный (РКИ), Слова-Обращения, Речевая Культура, Речевой Этикет, Собственные Имена, Персидский Язык.

1. E-mail: re_hassanzadeh@sbu.ac.ir 


\section{Введение}

Одной из особенностей, которые вызывают многочисленные трудности для иранской аудитории, являются слова-обращения, т.е. слова или сочетания слов, называющие адресата речи, с помощью которых одно лицо обращается к другому. (Стариченок 2008.302)

Цель данной статьи состоит в том, чтобы, ссылаясь на языковой материал двух языков, охарактеризовать особенности обращений русского и персидского этикета, которые отражают материальную и морально-духовную культуру народов этих двух стран. Результаты данного исследования могут быть полезными не только для студентов, изучающих РКИ в иранской аудитории, но и для русскоговорящих учащихся персидскому языку как иностранному, так как коммуникативные потребности учащихся, желание научиться хорошо владеть русским или персидским языком зримо ощущается со стороны учащихся обоим языкам как в иранской, так и российской аудиториях. В данной работе используются описательный и сравнительносопоставительный методы.

\section{Основная часть}

Как известно, во всех языках мира существуют слова, с помощью которых в различных коммуникативных ситуациях люди обращаются к другим лицам с целью привлечь их внимание к себе. В лингвистике русского языка подобные слова носят названия «обращения» или «вокативные слова» (или просто «вокативы»). В Большом лингвистическом словаре В.Д. Стариченок описывает обращения, как «слова или сочетания слов, называющие адресата речи и характерные для русской речевой культуры.» (Стариченок 2008.302) Это такие слова как: господин, молодой человек, пап, папаша, мам, мамуля, мамка, Сережа, Сашка, Сашенька, дядька, гражданин, ть-обращение, выобращение, пацан, гражданочка, начальник и т.д., которые в русской речевой 
культуре активно употребляются, но каждое из них помимо лингвистических особенностей, в зависимости от коммуникативной ситуации и намеренения говорящего и ряда других экстралингвистических факторов обладает узким ситуативным употреблением. Уместное употребление подобных слов и выражений обращения весьма важно для учащихся РКИ, так как неуместное употребление обращений может посчитаться невоспитанностью и проявлением неуважения к адресату.

Согласно лингвистическим учениям об обращениях русского языка, обращения представляют собой «формально не включенное в состав предложения слово или словосочетание, называющее того, к кому обращается говорящий, т.е. употребляющееся с целью привлечь внимание того лица, к которому обращается говорящий» (Ахманова О. С. [Электронный ресурс]. Режим доступа: www.classes.ru/grammar/174.Akhmanova/ Ахманова. - Дата доступа: 21.10.2017). С синтаксической точки зрения применительно к словам обращения С.Г. Ильенко в Коммуникативно-структурном синтаксисе современного русского языка излагает свою следующую точку зрения: «Под обращением понимается изолированное выражение, которое используется как самостоятельное высказывание с фиксированным коммуникативным заданием: одернуть адресата, напомнить ему о недопустимости нарушения неких парвил» (Ильенко 2009.141).

Все вышеприведенные дефиниции касательно лингвистического описания обращения можно обобщить в следующем: «Обращение - это обособленный интонационно и грамматически самостоятельный компонент предложения или сложного синтаксического целого, служащий для обозначения лица или предмета, являющегося адресатом речи» (Фаткуллина 2012. 47).

Однако В.И.Карасик, в отличие от вышеупомянутого учения, не характеризует обращения в качестве чисто лингвистического феномена. Под понятием обращения он подразумевает «речевые акты и языковые единицы, 
посредством которых выражаются соответствующие языковые единицы. Слова, используемые в качестве обращения, выражают не только отношение говорящего к адресату, но и несут информацию о самом говорящем, о его воспитании, умении вести себя в социальном положении. Обращения существуют во всех языках, специфично отражают национально-культурные особенности языков, неоднородны по своему составу и имеют сложное содержательное строение». (Карасик 2002.67)

Таким образом, можно утверждать, что обращения помимо лингвистических особенностей дополнительно обладают коммуникативной значимостью и выполняют ряд речевых функций в процессе непосредственного речевого контакта. Следовательно, правила употребления подобных слов в речи разных народов мира регламентируются в тесной связи с лингвокультурологическими и коммуникативно-ситуативными факторами, которые в свою очередь образуют речевой этикет, действующий в той или иной речевой культуре.

Исследования в области речевого этикета свидетельствуют о том, что употребление слов-обращений сильно зависит от особенностей коммуникантов, вступающих в коммуникацию, т.е. социального статуса адресанта и адресата, их места в социальной иерархии, их профессии, национальности, вероисповедания, возраста, пола и характера; от речевой ситуации, в которой происходит речевое общение: темы, места, времени и цели общения; а также от национальных особенностей, т.е. каждый народ создает свою систему правил поведения, в том числе и речевого.

Как правило, обращения, в том числе и собственно-именные, выполняют две функции, обычно реализующиеся совместно: призывную (апеллятивную): это, когда определенное лицо (адресант) использует обращение лишь для того, чтобы привлечь внимание адресата, например Борис, скажи, пожалуйста, правду!; и оценочно-характеризующую (экспрессивную функцию): в которой 
помимо апеллятивной цели адресант преследует выражение своей субъективной оценки к адресату, например: Боренька (у адресанта положительные эмоции к Борису), как я рада тебя видеть! (Гольдин 2009. 81) В русском языке к первой функции обращений можно отнести такие стилистически нейтральные полные формы собственных имен, как Сергей, Николай, Александра, Владимир и т.д., которые в нейтральной коммуникативной обстановке употребляются в русской речевой культуре для обращения к лицам. Однако, подобные нейтральные обращения могут осложняться и дополнительной экспрессивно-оценочной окраской, и нести в себе дополнительную субъективную сему. Например, в русском языке существуют более ласкательные и эмоциональные обращения, обозначающие вышеуказанных лиц, которые в зависимости от намерения адресанта могут обращению придавать как положительную оценку, так и достаточно ярко отрицательную. Сравните, применительно к нейтральному обращению Сергей в русском языке существуют обращения с положительной ласкательной оценкой: Серёжа, Серёж, Серёга, Серёжка, Серёжечка, Серж, Сержик, и т.д. Неуместное употребление каждого из вышеперечисленных суффиксальных и сокращенных форм от полного имени Сергей, может внести в речевую ситуацию более отрицательную и невежливую окраску, и поспособствовать тому, чтобы адресат почувствовал неловкость и некое смущение в общении с адресантом; например, суффиксальная форма собственного имени Серёжка может в контексте получать одобрительную окраску (Сережка, ты просто молодец!) и неодобрительную (Сережка, ты чего не гасишь свой долг! А?).

Ильенко к этим двум функциям добавляет еще и ситуативноопределяющую. В качестве примера можно привести следующие обращения, которые в зависимости от конкретной речевой ситуации употреблены по отношению к одному и тому же лицу: Сергей, Сереженька, Серьга, Серёга и др. (Ильенко 2009: 217). 
В зависимости от отношений между говорящим и его собеседником языковое оформление обращения может различаться. Выделяют обращения по семейному статусу (Сережка, Боря, Петя), по гражданскому, социальному, политическому, профессиональному статусу или званию (Борис Иванович, Уважаемый Иван Петрович, Сергеев Иван Петрович), по половой принадлежности (тетя Маня, дядя Коля, ), по возрастной категории (Петька, Сан Саныч, Михальчч, дядя Ваня). (Формановская 2007. 298)

По степени официальности речевой ситуации обращения делятся на официальные, неофициальные и безличные. Они используются в зависимости от ситуации. Так, фамильярное обращение Талян, Толик (от имени Анатолий), даже между людьми одного возраста отнюдь не уместно в официальной речевой ситуации, а обращение Николай Петрович в дружеском коллективе, скорее всего, будет интерпретировано, как шутка. Безличное обращение обычно используют в общественном транспорте, в магазинах, на улице. К незнакомому человеку в общественном транспорте, в магазинах, обычно обращаются со словами «позвольте», «прощу прощения». В такой обстановке обращаться к человеку по половому признаку («мужчина», «женщина», «девушка») не следует. Такой вид обращения еще именуется как нулевое обращение. (Формановская 2009. 115) К знакомым людям обычно обращаются по имени, имени-отчеству, фамилии. (Электронный ресурс. - Режим доступа: http://www.etiquetterules.ru/ Дата доступа: 21.10.2017.) Как видно, наряду с ранее перечисленными коммуникативно-ситуативными факторами, на выбор соответствующего обращения влияет и то, насколько адресат знаком с адресантом речи. На этой основе обращения делятся на две группы: обращение к знакомому лицу, и обращения к незнакомому лицу.

Среди иранских лингвистов, специализирующихся по данной тематике, выдающимися являются: Модарреси, Джахангири Н., Кешаварз. Джахангири в своей книге «Язык - отражение времени, культуры, и мышления» (2008) 
пишет: «Появление новых слов и выражений в персидском языке, в том числе и обращений в рамках речевого этикета, тесно связано с социальным положением иранского общества, принадлежностью к социальным сословиям, родственными отношениями, религиозными, половыми и возрастными признаками коммуникантов». (Джахангири 2008. 125)

Кешаварз также описывает и классифицирует новые слова-обращения, которые появились и стали употребляться в персидском языке после совершения Исламской революции в Иране. Им анализируются обращения в персидском языке исходя из социальных и идеологических убеждений иранского народа. (Keshavarz 1988. 566)

Далее с учетом вышеперечисленной коммуникативной специфики обращений будут рассматриваться собственно-именные обращения, употребляемые в русской речи, и с помощью сопоставительного метода будут анализироваться их персидские эквиваленты, с тем, чтобы выявить сходные и отличительные черты таких форм обращений в русском и персидском языках.

Как правило, во всех языках мира одной из более ярких функций личных имен (а также фамилий и отчеств) является призывная (апеллятивная), т.е. они могут употребляться для обращения к тому или иному адресату. В русском языке особенность обращений по собственным именам заключается в том, что система собственных имен русского языка состоит из трех компонентов: имя, отчество, фамилия. Исходя из этого, в русской речевой культуре существует множество форм обращений, выраженных с помощью личного имени в качестве обращения. Это разнообразие осложняется многочисленностью сокращённых форм имени (а также отчества). Однко, здесь необходимо учесть тот факт, что в зависимости от коммуникативной ситуации речи, включая деловую, дружескую, семейную и т.п. в русском языке отличаются различные виды обращений по собственным именам и фамилиям.

Что же касается речевого этикета персидского языка, то обращения по 
собственным именам в этом языке не столь разветвленные, как в русском. Именная система персидского языка включает в себя как максимум два компонента: имя и фамилия. Отчества в персидском языке не употребляются. Следовательно, обращения по личным именам в персидском языке классифицируются по пяти типам:

- обращения по имени: حسن [hasan]

- Обращения по фамилии: احمدى [ahmadi]

- Полное официальное обращение по имени и фамилии: حسن احمدى [hasane ahmadi], которое, как правило, образуется с помощью изафетного показателя (- э) между двумя компонентами изафетной конструкции со значением родста, т.е. первый компонент конструкции обозначает имя лица, которое принадлежит к роду, обозноченному вторым компонентом в изафетной конструкции: в вышеприведенном примеое حسن حسasan] принадлежит роду احمدى [ahmadi].

- Обращение по «имени + притяжательное местоимение»:

[mohammadam]. В подобных обращениях по имени слово-обращение помимо апеллятмвной функции осложняется еще и экспрессивно-оценочной окраской с ласкательным значением. Оно может употребляться по отношению к любимому человеку, как например к супругу или ребенку и т.п.

- Обращения по имени и фамилии в сочетании со словами, указывающими возрастную, половую, религиозную, социальную, профессиональную и даже

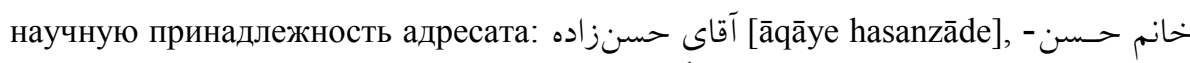

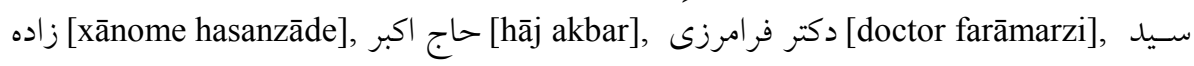

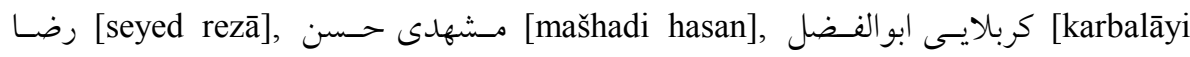

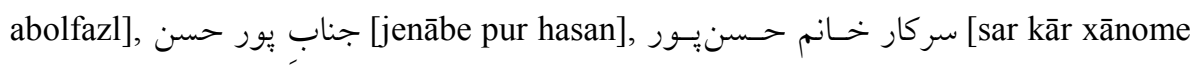
hasan pur], حسن آَّان [hasan āqā] и т.д.

Далее будут анализироваться формулы обращений в русском языке в сопоставлении с персидским языком. В русском языке в зависимости от 
степени знакомства, положения и условий общения употребляются следующие формулы обращений (Гвоздева 2008. 99):

1. Обращения-антропонимы типа господин (госпожа), товарищ, гражданин + фамилия: это вежливо-официальная форма обращения в публицистической и деловой речи русского языка, например господин (товарищ) Смирнов, гражданин Петоров. Эквивалентом выражения подобного рода слов-обращений в персидском языке является форма: آقـاى

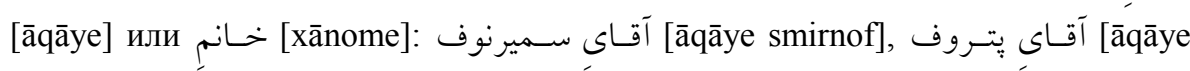
petrof]. Слова товарищь, гражданин, гражданка в персидской речевой культуре

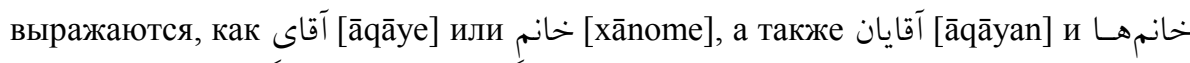
[xānomhā] в зависимости от пола адресата и его числа. В персидском же языке в официальном обращении представителей власти и государства иногда

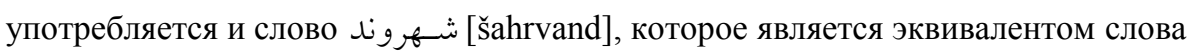

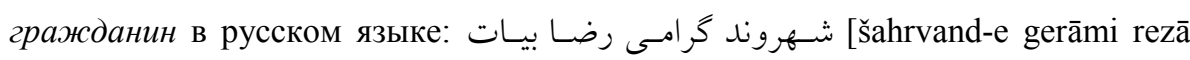
bayāt].

Иногда в русском языке для выражения более уважительного и официального обращения употребляется форма «Уважаемый (глубокоуважаемый) + имя + отчество», которая, как правило, встречается в письменных деловых текстах и переписках. Такая форма обращения адресуется по отношению к высокопоставленным чиновникам, деятелей культуры, науки, политики и т.п. В персидском языке для выражения этого

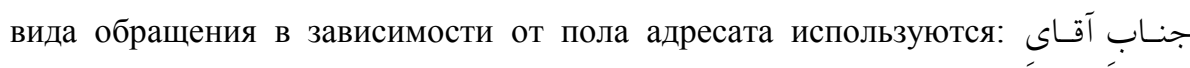
[jenāb-e āqāye] (применительно к мужчинам) и سـركار خـانم [sar kār-e xānome] (применительно к женщинам). Учащиеся РКИ в иранской аудитории должны учитывать, что подобные обращения употребляются исключительно в официально-деловых отношениях, и их употребление придает речевой ситуации официальность.

2. Имя + фамилия: это распространенная в русском языке форма 
вежливого обращения к взрослому человеку в официальной речевой обстановке: Иван Петров. В персидском языке данная форма обращения также используется в чисто официальной ситуации, и употребляется в публицистических текстах и репортажах корреспондентов, дикторов политических обозревателей и т.п., например в персидском языке иногда в спортивных рубриках можно вычитать такие выражения, как على دايسى

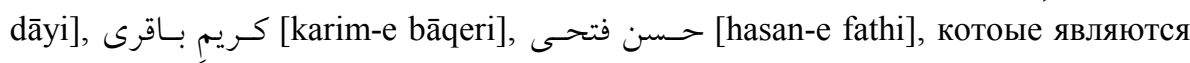
спортивными и кинематографическими деятелями в Иране, в публицистических текстах корреспонденты или журналисты или обозреватли называют деятелей различных сфер деятельности по имени и фамили. В персидском языке форма «имя+фамилия» используется и в ситуации, когда делается перекличка на занятии или в других мероприятиях. Для вежливого обращения к взрослому человеку в персидском языке употребляется форма «фамилия» в сочетании с обращениями-антропонимами: آَّاى [āqāye] или خـانم [ха̄nome]. Конечно же, подчеркивая религиозные и профессиональные признаки адресата, в персидском языке перед фамилией могут употребляться религиозные и профессиональные титулы, такие как حاج حاج خـانم

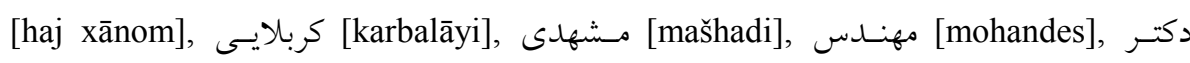
[doktor]. Иранским учащимся русскому языку необходимо учесть, что для перевода подобных обращений на русский язык лучше всего употреблять такие слова как господин или госпожа, либо обозначать их в русском тексте путем транслитерации подобных титулов: Кярбалаи, Хаджи, Мохандес, Машхади и т.д.

3. Имя + отчество: это самая распространенная в русском языке форма вежливого уважительного обращения к взрослому человеку. Данная форма также употребляется для представления при знакомстве и обращения к адресату, она является уважительной и сближающей. По отношению к детям шутливо-ироничное, игровое: Николай Петрович. Неупотребление отчества 
при обращении к старшему по возрасту, уважаемому человеку является нарушеним норм русского речевого этикета. Учащиеся РКИ в иранской аудитории часто задаются вопросом, не умаляет ли вежливости и официальности общния в русском языке употребление личного имени адресата в обращении. Данный вопрос у иранских учащихся проистекает из иранского речевого этикета. Так как в Иране в официальной обстановке не употребляется личное имя адресата, а называется лишь его фамилия вместе со جنـاب_ خانم سـر كار خـانم [jenāb-e āqāye] иār-e xānome], а при подчеркивании его научного и социального и профессионального статуса могут употребляться и

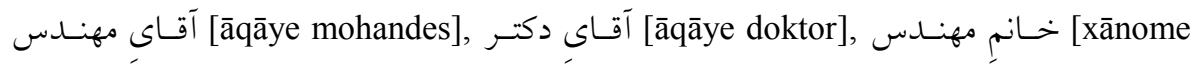
mohandes], آقاى يروفنسور [āqāye profesor] и т.п.

4. Имя + отчество + фамилия: данная форма обращения в русском языке обычно несет обращение биографического характера, и употребляется для представления адресата с целью знакомства, презентации какой-либо выдающейся личности в официальной речевой ситуации, например Николай Петрович Смирнов в русской речи употребляется для ознакомления аудитории с полным ФИО того или иного адресата. В персидском же языке из-за отсутствия имени отчества, эквивалентным обращением является форма «имя + фамилия» вместе со словами آقـاى [āqāye] и خـانم [xānome], а в болеe официальной обстановке جنـاب آقـاى xānome], a при подчеркивании его научного и социального и профессионального статуса могут употребляться и آقــاى مهنـــــ mohandes], آقاى دكتر [āqāye doktor], خانم مهندس [xānome mohandes], آقاى بِروفسور [āqāye profesor] и т.п.

5. Отчество: данный вид обращения является уважительным среди пожилых людей. Возможно в знак уважения обращение к молодым специалистам. Среди подростков в городе - к молодым наставникам, тренерам 
и т.П., например Петрович; в более неофициальной обстановке в русском языке бытуют более сокрощенные формы отчеств, например, отчествообращение Михалыч, образованное от Михайлович, и употребляемое для уважительного обращения в более неофициальной обстановке. В персидском же языке из-за отсутствия имени отчества, нет эквивалентных выражений подобных обращений руского языка. В персидском языке в подобной речевой ситуации для проявления большего уважения к пожилым людям могут употребляться слова, обозначающие их религиозные или социальные признаки

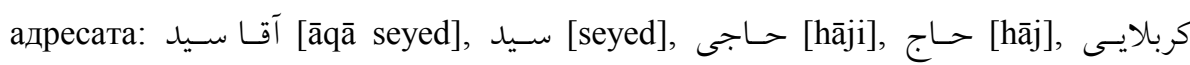
[karbalāyi], مشدى [mašdi] или عمو [amu] и т.д.

6. Фамилия: данная форма обращения в русском языке считается нейтральной в учебной среде. В производственных и бытовых отношениях как обращение стилистически снижено, фамильярно, а как называние 3 лица и самоназывание 1 лица при знакомстве представляет собой нейтральное и официальное обращение: Смирнов. Можно утверждать, что данное обращение русского языка полностью соответствует форме обращения в персидской речи, так как в персидском языке в нейтральной и более официальной обстановках речи предпочтение отдается употреблению фамилии в качестве обращения: [hasanzāde], احمـــ [ahmadi]. Иногда для проявления более уважительного отношения к адресату могут использоваться и слова قـاى [āqāye] и خانم [ха̄nome], а в более официальной обстановке جنـاب آقـاى [jēb-e āqāye] и سـركار خــانم [sar kār-e ха̄nome], а при подчеркивании его научного и социального и профессионального статуса могут употребляться и مهنــ [āqāye mohandes], آقاى دكتر [āqāye doktor], خانم مهندس [xānome mohandes], آقـاى [āqāye profesor] и т.п.

7. Личное имя: полная форма имени употребляется в русской речи в неофициальной ситуации. Как правило, это обращение к хорошо знакомому, близкому человеку. Оно также может получать оттенок строгости: Николай! 
Давай собирайся скорее же! Обычно в неофициальной семейной и дружеской обстановке относительно детей полное имя не употребляется, вместо него предпочтительнее употреблять суффиксальные формы личных имен, о которых речь пойдет в следующем пункте: Коля! Коль! А ну-ка иди сюда! В персидском языке в указанных речевых ситуациях употребляются личные имена адресатов: احمــ [ahmad], حسـ [hasan]. По этому виду обращений русский язык сходен с персидским языком.

8. Сокращенные формы личных имен: это сокращенная форма, обозначающая «свой», близкий, равный или младший по возрасту, положению; данная форма обращения используется в неофициальном общении. В русском языке она довольно часто употребляется и образуется от всех русских личных имен: Николай-Коля, Александр-Саша, Сергей-Серёжа, Иван-Ваня, Пётр- Петя и т.д. При знакомстве русский человек при желании сблизиться с адресатом, может ему предложить называть его по сокращенной форме своего личного имени: Можно просто Саша! В персидской речи система сокращенных имен не такая развитая и разветвленная как в русском языке. В ней встречаются такие сокращенные имена, как محمَـ مَد

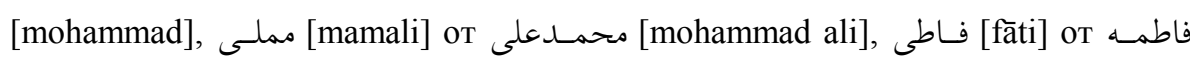

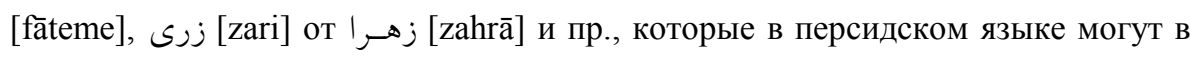
себе нести отрицательную и порицающую окраску. Однако данный способ образования сокращенных имен достаточно непродуктивный, поэтому русскоговорящие учащиеся персидскому языку как иностранному должны учитывть, что персидские личные имена не сокращаются по аналогии русского языка. В персидском языке для ласкательного и дружеского обращения к адресату к концу имени обычно присоединяется ласкательный показатель $ى$ [i], который к общению придает более неофициальность при дружеских отношениях: حسن [hasan] - حسنى [hasani]. Также в персидском языке для выражения теплых, дружеских и близких отношений к адресату после личного 
имени употребляют слово جان [jān]: حسن جان [hasan jān].

9. Суффиксальные формы личных имен: этот вид обращения употребляется в русском языке по отношению к «своему», близкому человеку, с одобрительной окраской. Коленька, Колюша, Колька. В персидской речи эквивалентом выражения суффиксальных форм личных имен могут служить эксперссивно-оценочные слова, как прилагательные كوجئه [aziz], а также دوستداشـتنى [dust dāštani], или же притяжательный показатель первого лица م- [-m]: Коленька: نيكـالاى عزيـز [nikolāye aziz], Андрюша [āndreye dust dāštani-am], Колечка دوست دواشتنىام kučulu va azizam]. Данный вид обращения в семейной и неофициальной обстановке в обязательном порядке употребляется для обращения к маленьким детям, что в персидском языке обычно выражается с помощью прилагательных с одобрительным значением, либо ласкательноуменьшительных средств персидского языка: على كو:حو [ali kučulu], [hasani]. Иногда взрослые в обращении к маленьким детям могут употреблять более официальную форму, которая помимо чувства одобрения адресанта к адресату, еще и выражает некую строгость взрослого к ребенку: علسى آقـإ [ali $\bar{a} q \bar{a}]$.

10. Ново-звательные формы собственных имен с помощью родительного падежа: в разговорной речи имена собственные, их сокращенные формы и существительные, обозначающие разные степени родства (мама, папа, дедушка, бабушка, дядя, тётя), в функции обращения нередко принимают особую - усеченную - форму, без окончания, которую некоторые языковеды считают особым звательным падежом, совпадающим с формой родительного падежа множественного числа. Данные звательные формы, ограниченные разговорно-обиходной сферой, очень часто употребляются в неофициальной дружеской и семейной коммуникативной ситуации. Они образуются от собственных имен, которые оканчиваются на 
окончание - а или -я: Таня-Тань, Варвара-Варвар, Гена-Ген, Вася-Вась, КоляКоль и т.п.: Коль, поди-ка сюда, дело есть! В речевой культуре персидского языка из-за отсутствия падежных форм в этом языке, нет эквивалентных флрмул в обращении к адресатам. Существует лишь способ сокращения некоторых собственных имен, который совпадает по употреблению с данной

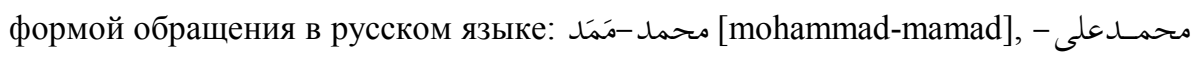
[mohammad ali-mamali].

11. Дядя (тётя) + имя: это неофициальное, сближающее обращение. Вопервых, со стороны племянников, во-вторых, со стороны детей к друзьям родителей; в третьих, к пожилым людям «простых» профессий: нянечкам в школе или больнице, сторожам и т.п., например дядя Коля, тетя Маня. В персидском языке в качестве эквивалентов двух первых вышеперечисленных употреблений в зависимости от половой принадлежности адресата перед личным именем используются либо عمـو [amu] (применительно к мужчинам), либо خالـ [ха̄le] (применительно к женщинам). Относительно третьего употребления данной формы обращения в русском языке необходимо отметить, что здесь эти два языка отличаются в употребляемых словахобращениях. В персидском языке эквивалентным выражением в данной

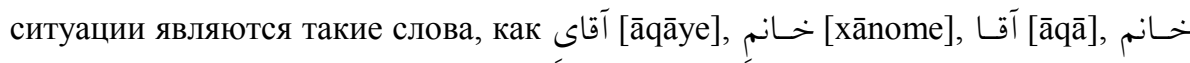
[xānom], حاج آقاج خانم [haj āqāaj xānom].

\section{Заключение}

Анализ и рассмотрение слов-обращений с помощью собственных имен в русском и персидском языках показал, что можно ли назвать человека по его собственным именам (личному имени, фамилии, отчеству) или нет, зависит от совокупности факторов коммуникативной ситуации: это степень знакомства с адресатом, официальность или неофициальность речевой ситуации, возраст и социальный фактор адресата, и его половая принадлежность, здесь также 
учитываются лингвокультурологические, мировоззренческие особенности, как адресатов, так и адресантов общения, и даже их личностные черты характера и манеры их поведения. Если адресант обращается по форме обращения, адекватной той или иной коммуникативной ситуации, то он закладывает прочную основу хорошим отношениям. Проведенное исследование данной темы свидетельствует о том, что в русском языке существует порядка 11 форм обращений, которые выражаются с помощью собственных имен адресатов. Результаты исследования показали, что в русском языке обращение по имени отчеству уместно при общении с человеком, которого адресат видит впервые, старшим по возрасту, выше по статусу и должности. Обращение по имени отчеству служит подтверждением важности адресата, признания качеств, достоинств, возможностей, статуса. Такой ход вызывает у него моральное удовлетворение, помогает склонить в сторону адресанта. Обращение по одной из 11 вышеперечисленных форм в русском языке представляет собой простой и действенный способ обратить на себя внимание другого человека, побороть неприязнь и недоверие, вызвать симпатию, построить продуктивный диалог, получить желаемый результат.

\section{Литература}

1- Ахманова О.С. Словарь лингвистических терминов (электронный ресурс). http://www.classes.ru/grammar/174.Akhmanova/ (дата обращения: 21.10.2017)

2- Гвоздева Е.В., Косицына Е.Ф., Орлова В.Н., Чирич И.В. (2008). Русский язык и культура речи: Учебное пособие для студентов нефилологических специальностей. -М.: Изд-во «МГИУ».

3- Гольдин В.Е. (2009). Обращение: теоретические проблемы/ Под ред. Л.И. Баранниковой. - 2-е изд. - М.: Изд-во Книжный дом «ЛИБРОКОМ».

4- Джахангири Надер (1387/2008). Забан, Базтаб заман, Фарханг ва андимех. Тегеран: Изд-во «Агах».

5- Ильенко С.Г. (2009). Коммуникативно-структурный синтаксис современного русского языка. СПб: Изд-во РГПУ им. А.И. Герцена. 
6- Карасик В.И. (2002). Язык социального статуса. - М.: Изд-во ИТДГК «Гнозис».

7- Стариченок В.Д. (2008). Большой лингвистический словарь. - Ростов н/Д: Издво «Феникс».

8- аткуллина Ф.Г., Сулейманова А.К. и др. (2012). Современная лингвистика и межкультурная коммуникация: монография. В 2 книгах. - Одесса: Куприенко C.В., - Кн. 2.

9- Формановская Н.И. (2007). Речевое взаимодействие: коммуникащия и прагматика. -М.: Изд-во «ИКАР».

10- Формановская Н.И. (2009). Речевой этикет в русском общении. Теория и практика. -М.: Изд-во «ИКАР».

11- Keshavarz, H.M. (1988). Forms of Address in Post-Revolutionary Iranian Persian: A Sociolinguistic Analysis. Language in Society.

12- http://etiquetterules.ru/osobennosti-etiketa/157-vidy-obraschenij.html (дата обращения: 24.10.2017)

\section{Bibliography}

1- Ahmanova O.S. Slovar' lingvisticheskih terminov (jelektronnyj resurs). http://www.classes.ru/grammar/174.Akhmanova/ (data obrashhenija: 21.10.2017)

2- Gvozdeva E.V., Kosicyna E.F., Orlova V.N., Chirich I.V. (2008). Russkij jazyk i kul'tura rechi: Uchebnoe posobie dlja studentov nefilologicheskih special'nostej. M.: Izd-vo «MGIU».

3- Gol'din V.E. (2009). Obrashhenie: teoreticheskie problemy/ Pod red. L.I. Barannikovoj. - 2-e izd. - M.: Izd-vo Knizhnyj dom «LIBROKOM».

4- Dzhahangiri Nader (1387/2008). Zaban, Baztab zaman, Farhang va andisheh. Tegeran: Izd-vo «Agah».

5- Il'enko S.G. (2009). Kommunikativno-strukturnyj sintaksis sovremennogo russkogo jazyka. SPb: Izd-vo RGPU im. A.I. Gercena.

6- Karasik V.I. (2002). Jazyk social'nogo statusa. - M.: Izd-vo ITDGK «Gnozis».

7- Starichenok V.D. (2008). Bol'shoj lingvisticheskij slovar'. - Rostov n/D: Izd-vo «Feniks».

8- Fatkullina F.G., Sulejmanova A.K. i dr. (2012). Sovremennaja lingvistika i mezhkul'turnaja kommunikacija: monografija. V 2 knigah. - Odessa: Kuprienko S.V., - Kn. 2.

9- Formanovskaja N.I. (2007). Rechevoe vzaimodejstvie: kommunikacija i pragmatika. -M.: Izd-vo «IKAR». 
10- Formanovskaja N.I. (2009). Rechevoj jetiket $\mathrm{v}$ russkom obshhenii. Teorija i praktika. -M.: Izd-vo «IKAR».

11- Keshavarz, H.M. (1988). Forms of Address in Post-Revolutionary Iranian Persian: A Sociolinguistic Analysis. Language in Society.

12- http://etiquetterules.ru/osobennosti-etiketa/157-vidy-obraschenij.html (data obrashhenija: 24.10.2017).

\section{HOW TO CITE THIS ARTICLE}

Hasanzadeh Rezvan (2018). Application of Proper Nouns as Terms of Address in Russian Compared to their Persian Equivalents, Issledovatel'skiy Zhurnal Russkogo Yazyka i Literatury,11(1): pp: 215-233

DOI: $10.29252 /$ iarll.11.215

URL: http://journaliarll.ir/article-1-112-en.html

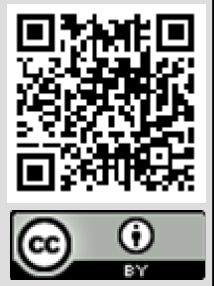


بررسى كاربرد اسامى خاص به عنوان كلمات خطاب در زبان روسى در مقايسه با معادلهاى آنها در زبان فارسى

\author{
رضوان حسنزاده' \\ استاديار كروه زبان و ادبيات روسى و اسلاوى دانشكاه شهيد بهشتى، رواده

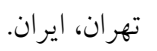

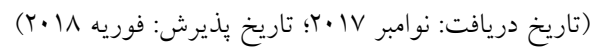

مقاله به بررسى كاربرد اسامى خاص اشخاص در نقش كلمات خطـاب در زبـان روسى و و

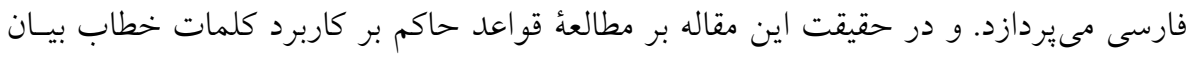

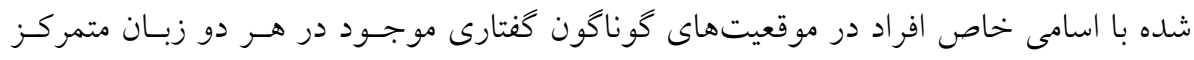

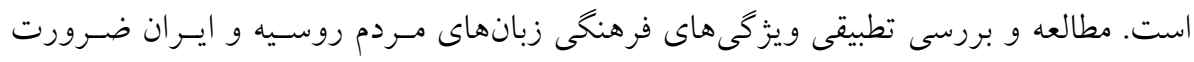

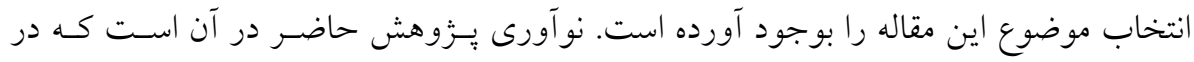

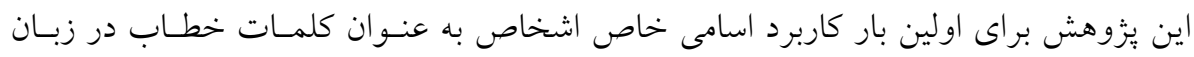

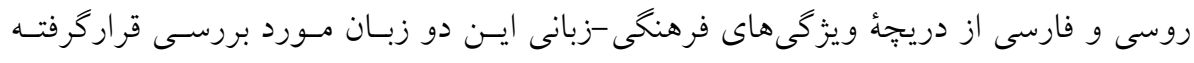

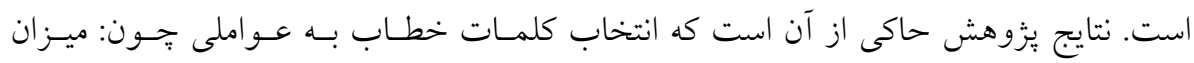

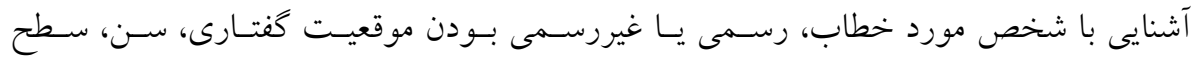

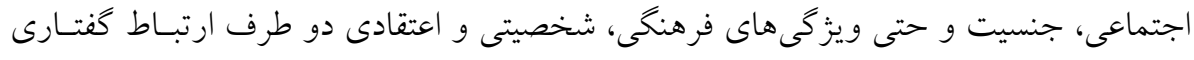

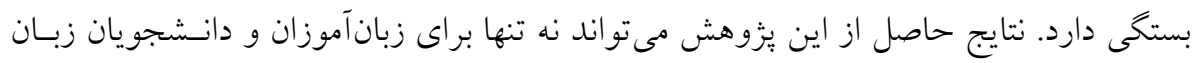

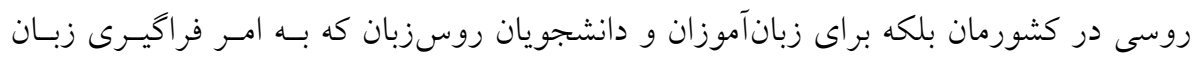

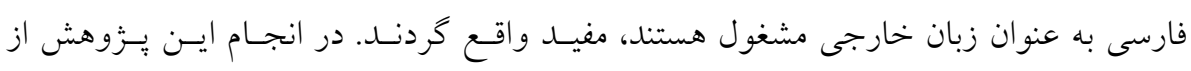
روشهاى تحقيق توصيفى و تطبيقى -مقايسهاى زبانشناسى استفاده شده است.

وازگكان كليدى: زبان روسى به عنوان زبان خارجى، كلمات خطـاب، فرهنـع كفتـار و سـخن، آداب سخن، اسامى خاص اشخاص، زئس زيان فارسى. 